Cite as: Grohmann, C.H., Miliaresis, G., 2013. Geological applications of digital terrain analysis. International Journal of Geographical Information Science. 27:1403-1404.

DOI:10.1080/13658816.2013.772617

\title{
EDITORIAL \\ Geological applications of digital terrain analysis
}

Terrain analysis (Way 1978) includes segmentation (the terrain partition framework), pattern recognition (objects classification and mapping) and decision making for site eval- uation, site selection and environmental analysis studies (Lillesand and Kiefer 1987). Nowadays, digital elevation models (Pike 1995) are freely available through the Internet such as the Shuttle Radar Topography Mission (Farr et al. 2007), providing a way to look at our planet with an unprecedented detail, often allowing the recognition of previously unknown features and the establishment of their spatial relationships. In addition, global and regional land cover characteristics and various biophysical datasets (land surface temperature, sea surface temperature) are acquired on a day and night basis from modern imagery, giving rise to various environmental applications (Miliaresis 2009).

Geologic terrain analysis includes, among others, the recognition and monitoring of landslide prone areas, evaluation of tectonic and fluvial processes in an attempt to estimate natural hazards, and evaluation of terrain suitability for engineering project design. Geologic terrain analysis is benefited from modern digital elevation models, landcover and multi-temporal biophysical data availability, while a variety of quantitative techniques have been developed to automate its processing. In this volume, the modern advances in the field of geological terrain analysis are presented, while emphasis is given to the quantitative analysis of modern datasets. Five case studies are presented:

1. Brunori et al. used a high-resolution digital elevation model derived from an airborne light detection and ranging (LiDAR) campaign in an attempt to characterise the structural and erosive elements of the geometry of the Pettino fault, a seismogenic normal fault in Central Apennines (Italy). At first, the conceptual framework for fault scarp evolution as well as the structural elements of fault morphology are defined and verified within the geological setting of the specific study area. Then, geomorphometric parameters are calculated from the LiDAR DEM while statisti- cal analyses allow the recognition of processes related to fault evolution and the estimation of long-term slip rate.

2. The definition of Maximum Branch Length (Bmax), a new topographic attribute derived from digital elevation models, is presented by Lindsay \& Seibert. Branch length is defined as the distance travelled along a flow path initiated at one grid cell to the confluence with the flow path passing through a second cell while Bmax is the longest branch length measured for a grid cell and its eight neighbours. The index provides a physically meaningful method for assessing the relative significance of drainage divides to the dispersion of materials and energy across a landscape, that is, it is a measure of 'divide size'. Bmax is particularly useful for studying divide network structure, for mapping drainage divides and in landform classification applications.

3. A new context for active tectonic zone recognition is proposed by Miliaresis on the basis of the exporting energy of the terrain features at continental scale. The combined analysis (constraint elevation, latitude, longitude dimension reduction of multi-temporal land surface temperature) of digital elevation data and multi-temporal biophysical datasets allowed the identification and mapping of active tectonic processes along (a) the Himalayan Belt along the Pakistan, Afghanistan borders and the Eastern Alpine zone (Makhran Ranges and Zagros Ranges), (b) the coastal zone (along the Red Sea) of the Arabian shield and (c) the Oman Mountains Province along the Persian Gulf.

4. Segoni et al. present an assessment of landslide susceptibility in Sicily (Italy) at regional scale using a multivariate logistic regression model. The model was implemented in a GIS 
environment by using the Arc Spatial Data Modeller module, modified to develop spatial prediction through regional data sets. A newly developed algorithm was used to automatically extract the detachment area from mapped landslide polygons. The following factors were selected as independent variables of the logistic regression model: slope gradient, lithology, land cover, a curve number derived index and a pluviometric anomaly index. The results of the analysis were validated using an independent landslide data set provided by the Ministry of Public Works of Italy. On an average, $82 \%$ of the area affected by instability and $79 \%$ of the not affected area were correctly classified by the model, which proved to be a useful tool for site selection and engineering project design.

5. The Auca Mahuida (2.03-0.88 Ma) is the southernmost volcanic field of the Payenia volcanic province, in the Andean foreland (Neuquén Basin, Argentina). Geomorphometric analysis by Ventura et al. indicates that Auca Mahuida consists of a basal, EW elongated lava field with monogenic vents and a summit, polygenic, also EW elongated, cone. A N100E striking fault controls the southern flank of the field, which is also affected by scarps related to erosional and gravity-controlled processes. Drainage network shows a pseudo-radial pattern around the summit cone, and Auca Mahuida's deepest valley is structurally controlled by a NNWSSE striking fault affecting the sedimentary basement. The volcanic field lies on a NE to E dipping substratum. The areal distribution of the monogenic cones is consistent with ascent of magmas along EW striking fractures, and with elastic models of a magma chamber subjected to an EW compression.

Carlos Grohmann

Universidade de Sao Paulo, Brazil

Email:guano@usp.br

George Miliaresis

Remote Sensing $\&$ GIS Center, Muscat, Oman

Email: miliaresis.g@gmail.com

\section{References}

Farr, T.G., et al., 2007. The shuttle radar topography mission. Review of Geophysics, 45, RG 2004.

Lillelsand, T. and Kiefer, R., 1987. Remote sensing and image interpretation. 2nd ed. New York: John Wiley \& Sons.

Miliaresis, G., 2009. Biophysical terrain analysis. In: R.T. Mancuso, ed. Environmental cost management. New York: Nova Science Publishers, 255273.

Pike, R.J., 1995. Geomorphometry-process, practice and prospects. Zeitshcrift F. Geomorphologie N.F. Suppl. Bd, 101, 221238.

Way, D., 1978. Terrain analysis. New York: McGraw-Hill. 